\title{
INFLUENCE OF LEGUMES ON SOIL FERTILITY IN STRAWBERRY - LEGUME INTERCROPPING
}

\author{
Sandra Dane ${ }^{1,2}$, Valda Laugale ${ }^{1}$, Līga Lepse ${ }^{1,2}$, Dace Siliņa ${ }^{1}$ \\ ${ }^{1}$ Latvia University of Agriculture \\ ${ }^{2}$ Pūre Horticultural Research Centre, Latvia \\ sandra.dane@1lu.lv
}

\begin{abstract}
Legumes are becoming more popular in food and feed consumption. They are promoted by EU policy related to healthy lifestyle and environmental policy. Legumes can be grown in crop rotation as monocrop or in different kind of intercropping systems. It is a well known fact that legumes play an important role in fixation of the atmospheric $\mathrm{N}$, whereas their influence on other biological and chemical aspects of the soil ecosystem is only explored partially. The experimental trial was established at the Pūre Horticultural Research Centre with the aim of studying the influence of legumes on the soil properties in the intercrop with strawberries (Fragaria $\times$ ananassa Duch.). Different genotypes were included in the trial as intercrops: two local broad bean (Vicia faba var. major L.) genotypes, two pea (Pissum sativum L.) cultivars and clover (Trifolium hybridum L.). Two control treatments were included in the trial: with and without nitrogen fertilizer usage. Strawberries were planted in May of 2014 and maintained in the field for three years. Results showed that there were significant differences between treatments in soil respiration rate (SRR) and SRR dynamic throughout the experiment time. Dehydrogenase activity had similar results, though no significant differences between treatments were observed in the third year. No significant difference between treatments was found in the soil organic matter. Obtained data shows that legumes have a significant influence on the soil biological properties but not on biochemical properties. Further research needs to be carried out to determine legume influence on soil environment in more detail.
\end{abstract}

Key words: Vicia faba, Pissum sativum, Trifolium hybridum, soil biological activity, soil chemical properties.

\section{Introduction}

More and more farmers in EU are looking for possibilities to reduce chemical fertilizer usage with the aim to improve the sustainability of their farming systems and to reduce environmental load, to reduce growing costs and to supply customers with products grown in natural environment. Legume growing is being promoted to reduce the necessity for nitrogen fertilizer applications. Their ability to fix atmospheric nitrogen is well known, while their influence on environment, especially on soil properties, is not yet thoroughly studied. It is known that plants with deep and broad root system improve soil structure (Bardgett, Mamer, \& De Vries, 2014). Leguminous plants increase nitrogen content in soil. At the same time, some studies suggest that legumes do not increase nitrogen content in the soil but more likely keep it at the same level if plant leftovers are incorporated in the soil (Herdina \& Silsbury, 1990; Hayens, Martin, $\&$ Goh, 1993). Plants used for green manure or plant residues incorporated in the soil increase soil organic matter (Brennan \& Acosta- Martinez, 2017).

Strawberries are one of the most popular berries in the human diet. Their consumption increases every year (FAO, 2017). There are many different technological solutions used in their growing. Strawberries are mainly grown in the soil under open field condition. Significant area is left bare between strawberry rows in such production systems. Sustainable agriculture approach could promote using that space for food/ feed growing. Strawberries are in need of nitrogen not only during active growing but also in formation of inflorescence in autumn (Sønsteby et al., 2009). Including legumes in strawberry growing can give the necessary amount of nitrogen during formation of inflorescence if legume plant leftovers are incorporated in soil after the harvest of legume green pods (Jensen, Peoples \& Hauggaard- Nielsen, 2010). This research was performed to get a better knowledge of how legumes included in the intercropping influence the biological and biochemical soil properties. Three-year data of strawberry-legume intercropping system`s influence on soil fertility are presented in this paper.

\section{Materials and Methods}

The experiment was performed for three consecutive seasons from 2014 to 2016 at the Püre Horticultural Research Centre, Latvia, in $57^{\circ} 02^{\prime} 17.8^{\prime \prime}$ north latitude, $22^{\circ} 55^{\prime} 00.3^{\prime \prime}$ east longitude. Strawberry (Fragaria $\times$ ananassa Duch.) cultivar 'Polka' was planted as mine crop in the spring of 2014. Before plowing, the field was used as perennial meadow for harvesting hay. Strawberries were planted in rows with distance $1.0 \mathrm{~m}$ between rows and $0.3 \mathrm{~m}$ between plants in the row. Interplants were sown between strawberry rows as shown in Figure 1. Two local genotypes of broad beans (Vicia faba var. major L.) VF_01 and VF_02, two peas (Pissum sativum L.) sugar pea 'Ambrosia' and green pea 'Capella', alsike clover (Trifolium hybridum L.) 'Namejs' were used as intercrops. Two controls: with and without application of nitrogen fertilizer were included in the trial. Broad beans were sown in three rows with $0.25 \mathrm{~m}$ distance between rows and $0.20 \mathrm{~m}$ between plants in row. 


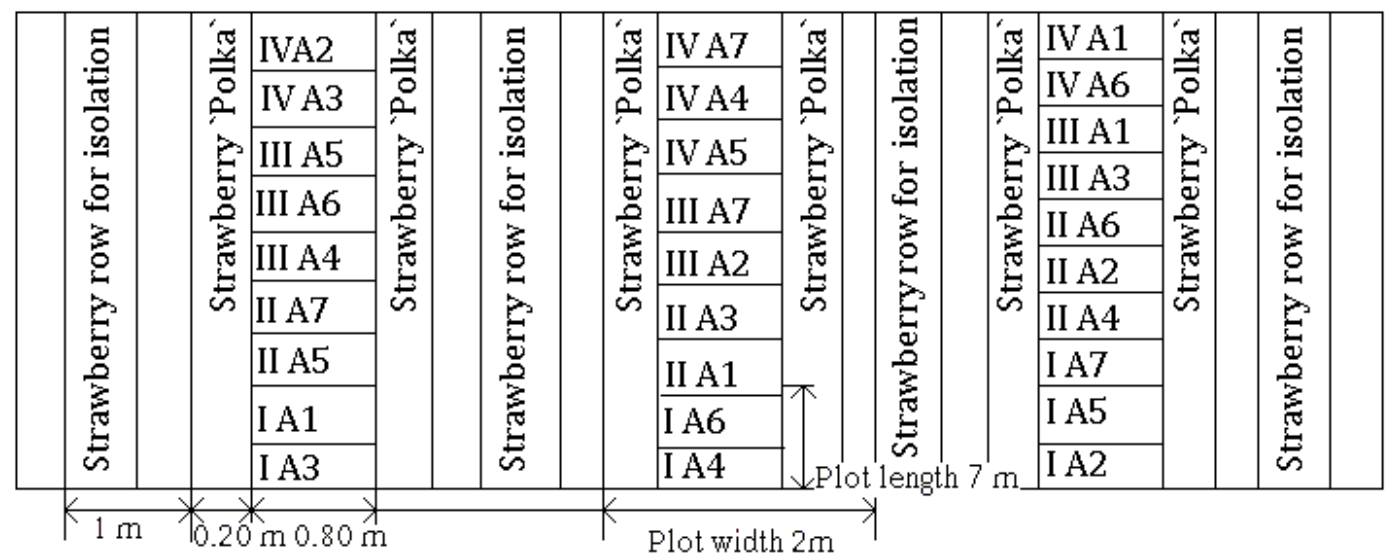

Figure 1. Experimental field layout: A1 - Broad bean genotype VF_02, A2 - Broad bean genotype VF_01, A3 - Pea 'Ambrosia', A4 - Pea 'Capella', A5 - alsike clover 'Namejs', A6 - control without N fertilizer, A7 control with $\mathrm{N}$ fertilizer, $\mathrm{I}-\mathrm{IV}$ replications.

Peas were sown in three rows with $0.25 \mathrm{~m}$ distance between rows and $0.1 \mathrm{~m}$ between plants in row. Alsike clover was sown in three rows with a seed rate of 6.4 $\mathrm{g} \mathrm{m}^{-2}$. In the control treatment with nitrogen fertilizer application, $\mathrm{Ca}\left(\mathrm{NO}_{3}\right)_{2}$ was used in a rate of $9.64 \mathrm{~g} \mathrm{~m}^{-2}$. In other treatments no nitrogen fertilizers were used. The plot size was $2 \times 7 \mathrm{~m}$ with isolation $2 \times 1 \mathrm{~m}$ from both plot ends, where the size of evaluation plot was $2 \times 5 \mathrm{~m}$. Alsike clover was mowed with lawn mower after reaching $0.15-0.20 \mathrm{~m}$ height, residues were left on spot.

Peas and beans were grown for obtaining immature pod yield. Immature bean pods were harvested once and peas three times per vegetation season when reached fresh consumption stage (BBCH 80 - beans, 79 - peas).

Soil samples for soil organic matter content determination were collected two times per season at the beginning and at the end of vegetation season. To determine soil biological activity, the soil samples were collected every 10 days during the vegetation season. To evaluate soil biological activity, soil respiration (SR), activity of dehydrogenase (DHA) and the content of soil organic matter were measured. Soil respiration was evaluated by the method of closed container method, where soil sample $(50 \mathrm{~g})$ was placed in a jar where low container with $5 \mathrm{~mL}$ of $0.1 \mathrm{MKOH}$ was placed inside. After exposing it for 24 hours at $28^{\circ} \mathrm{C}$ in dark, the liquid was titrated with $0.1 \mathrm{M} \mathrm{HCl}$. The amount of $\mathrm{CO}_{2}(\mathrm{mg})$ was calculated by using the (1) formula:

$$
\mathrm{CO}_{2}(\mathrm{mg})=\frac{(\mathrm{K}-\mathrm{A}) \times 2.2 \times 60}{\mathrm{~m} \times \mathrm{t}}
$$

where $\mathrm{K}$ - amount of titrated $0.1 \mathrm{M} \mathrm{HCl}(\mathrm{mL})$ in the control jar; A - amount of titrated $0.1 \mathrm{M} \mathrm{HCl}(\mathrm{mL})$ in the sample jar; $\mathrm{m}$ - soil sample weight $(\mathrm{g}) ; \mathrm{t}-$ incubation time ( $\mathrm{min})$.

DHA activity was detected according to Kumar et al. (2013) method (modified by Dane (2016)). One gram of soil sample was exposed to $0.2 \mathrm{~mL}$ of $0.4 \%$ INT (2-p-iodophenyl-3-p-nitrophenyl-5phenyltetrazolium chloride) and $0.05 \mathrm{~mL}$ of $1 \%$ glucose in $1 \mathrm{~mL}$ distilled water for at least 6 hours. The formed INTF is extracted by adding $10 \mathrm{~mL}$ methanol and actively shaking for $1 \mathrm{~min}$. INTF is measured spectrophotometrically at wave length $485 \mathrm{~nm}$. DHA activity was calculated by (2) formula:

$$
\begin{aligned}
& \text { Amount of } \operatorname{INTF}(\text { DHA activity })\left(\mu \mathrm{L} \times \mathrm{L}^{-1} \times \mathrm{h}\right)= \\
& =\frac{\left(-3 \mathrm{a}^{2}+4 \mathrm{a}\right) \times 86400}{(60 \times \mathrm{h})+\min }
\end{aligned}
$$

where a - reading from spectrophotometer, $\mathrm{h}$ incubation time in full hours, min - minutes over full hour.

Soil mineral analysis were performed in the Institute of Agroresources and Economics, Stende, where organic matter was determined using oxidation with $\mathrm{K}_{2} \mathrm{Cr}_{2} \mathrm{O}_{7}$.

Meteorological data were collected in the local meteorological station LUFFT, meteorological data registered every $10 \mathrm{~min}$ (Figure 2). Soil moisture was determined with HH2 WET-2 sensor. Temperature in the vegetation season of 2015 was registered lower than long-term observed temperature. Temperature conditions in 2014 and 2016 were similar, fluctuating in average around long-term observed. More expressed variations were observed for the amount 

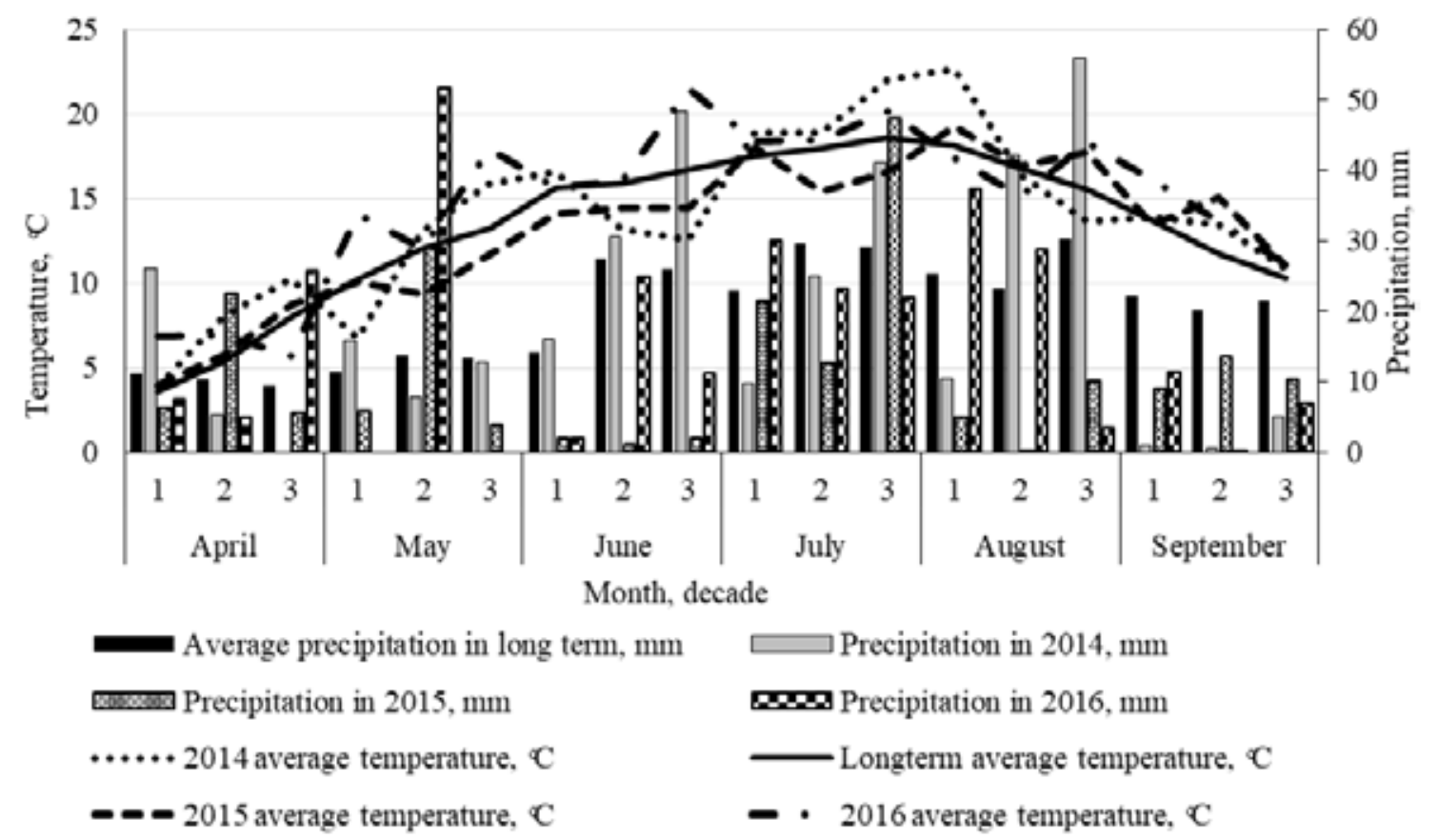

Figure 2. Long term meteorological data and meteorological data during experiment at Pūre

of precipitation. In 2014 the amount of precipitation was close to long-term data. During 2015 and 2016, the amount of precipitation was less in comparison to long-term data, especially at the end of May, beginning of July and the end of August, through all of September. These are critical periods for strawberry and legume development and yield formation. Reduced moisture can strongly influence the activity of soil microorganisms.

All data were subjected to analyses of variance (ANOVA) using STATISTICA (Dell Software, Round Rock, TX, USA) and the level of significance was set at $\mathrm{p}<0.05$.

\section{Results and Discussion}

Dehydrogenase activity was stated significantly different between the tested variants during almost all trial time (second year data shown in Figure 3 ). Only at the end of the third year there were no significant differences between treatments (data not shown). During the first and second growing year at the beginning of the vegetation season differences were minor, however, in the middle of the vegetation season differences became more significant $(\mathrm{p}<$ 0.001). Significant differences were observed between control without $\mathrm{N}$ fertilizer usage (Control $-\mathrm{N}$ ) and other treatments. There were small but significant differences between control with $\mathrm{N}$ fertilizer usage $(\mathrm{Control}+\mathrm{N})$ and treatments with legumes. Treatments with legumes not always showed higher DHA activity than in Control $+\mathrm{N}$. Mostly treatments with clover and pea 'Ambrosia' showed significantly lower DHA activity $(p<0.001)$ in the first growing year. Significant differences between treatments were observed also in the second growing year. Rapid decrease of DHA activity in August in the second growing year was due to dry period, when soil moisture capacity was stated below $8 \%$. Treatments with clover and pea recovered significantly faster when drought periods passed. During the third growing year no significant differences were observed between treatments $(p=$ 0.07 ). There is high probability that it was caused by dry period started at the beginning of the vegetation season and persisting until the end of June when trial ended. No significant differences in DHA activity were found between treatments with different legume genotypes $(\mathrm{p}>0.05)$.

Trial data shows significant decrease in DHA activity over the years in the treatments of intercropping strawberries with legumes. In the first growing year, the amount of INTF was from 80 to $100 \mu \mathrm{LL}^{-1} \mathrm{~h}^{-1}$, in the second and in third growing year it was only between 60 to $95 \mu \mathrm{LL}^{-1} \mathrm{~h}^{-1}$. That matches the findings of other research on microorganism activity where results show a significantly higher microorganism activity in soils with minimum tillage compared to conventional soil management (Dubova, Ruža, \& Alsina, 2016). It contradicts other research where microorganism activity and their biomass increased not only during the first years after the change of land use (Nautiyal, Chauha, \& Bhatia, 2010) but also later in soil management (Filser et al., 2002; Bischoff et al., 2016).

Soil respiration rate $(\mathrm{SRR})$ significantly $(\mathrm{p}<0.001)$ differed between treatments (Figure 4). Control $+\mathrm{N}$ showed the lowest respiration rate during the first and 

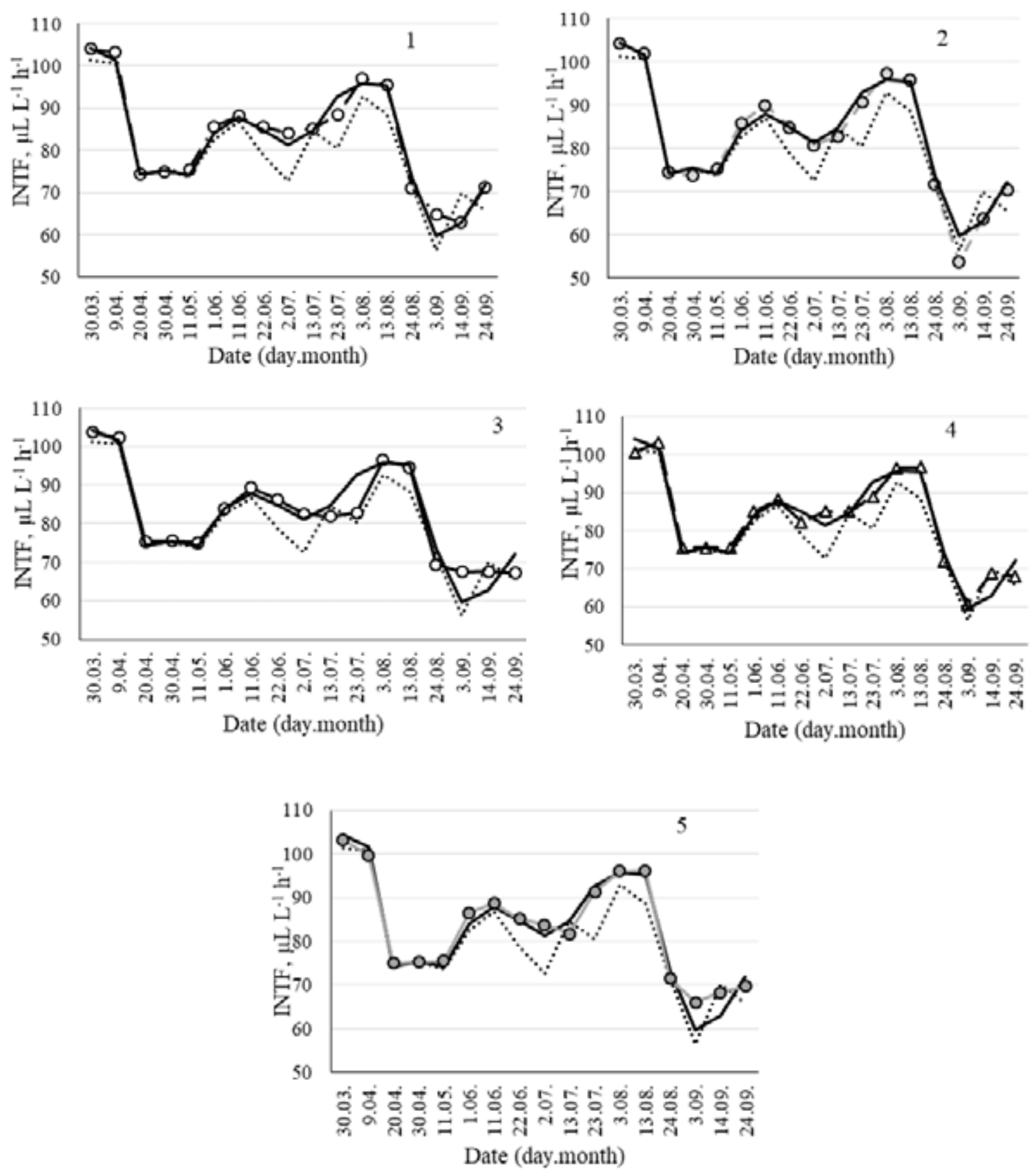

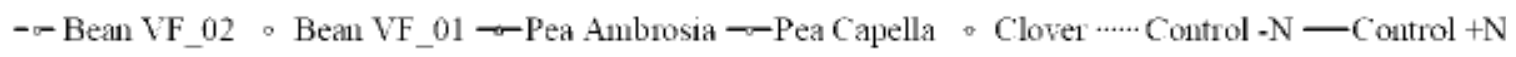

Figure 3. DHA activity in the two-year old strawberry - legume intercropping system (LSD0.05 $=1.23$ ). 1 - Bean VF_01 compared to both controls, 2 - Bean VF_02 compared to both controls, 3 - Pea 'Capella' compared to both controls, 4 - Pea 'Ambrosia' compared to both controls, 5 - Clover compared to both controls.

the second growing year. Combining results of soil respiration rate with DHA activity, it is clearly visible that in the Control $+\mathrm{N}$ treatment conditions were favourable for microorganism development, while not favourable for decomposition processes in soil done by chemical reactions as it was in the treatments with legumes and Control - N. In the third year, there were no significant differences in SRR between treatments (data not shown). The highest SRR was observed in the treatment with clover in the second growing year. It could be explained by regular clover mowing that increased dead root mass in the soil and green manure from regular clover mowing which served as $\mathrm{C}$ source for soil microorganisms. Data shows significant differences between growing years in SRR (data not shown), where SRR in the first year was significantly 


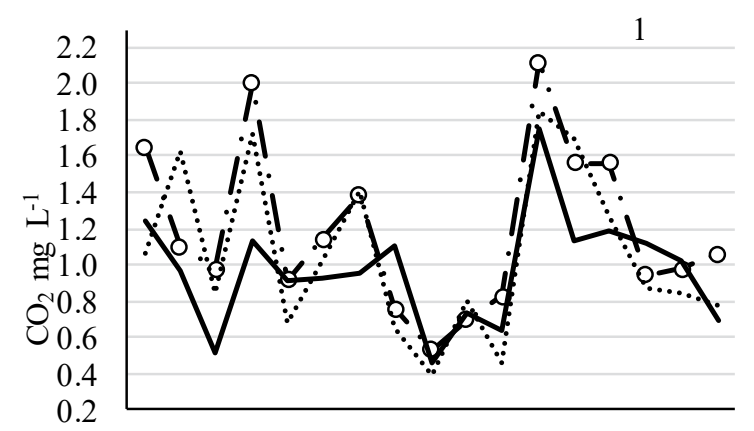

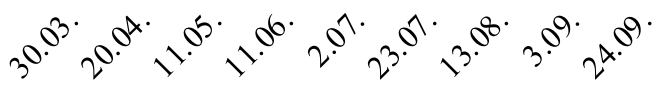

Date (day.month)

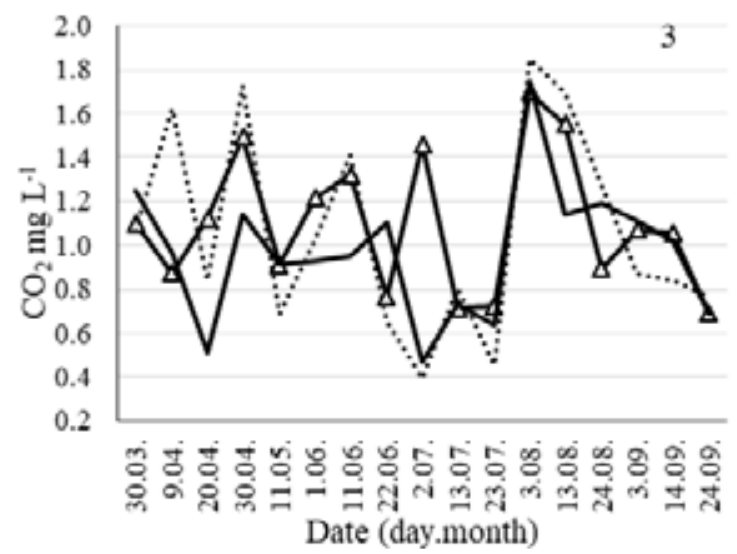

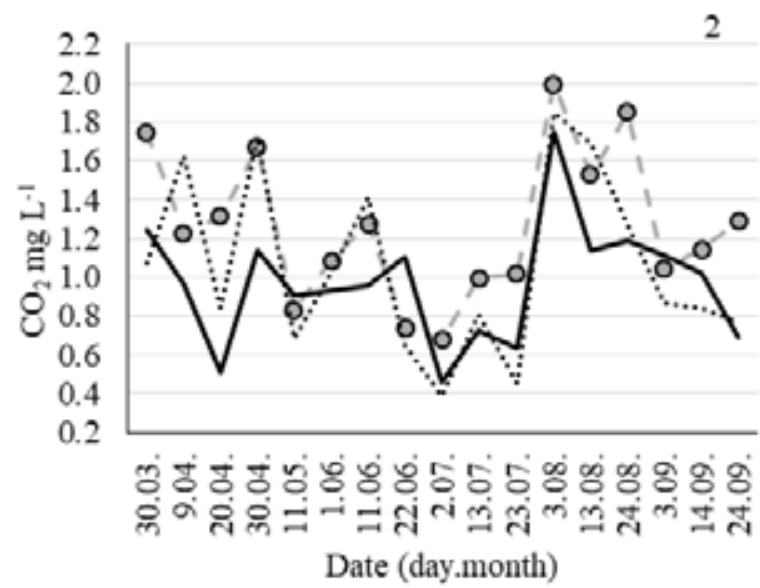

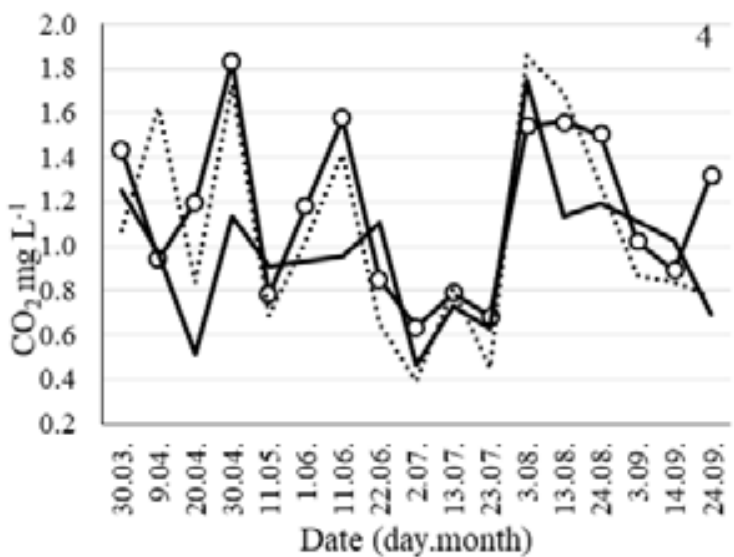

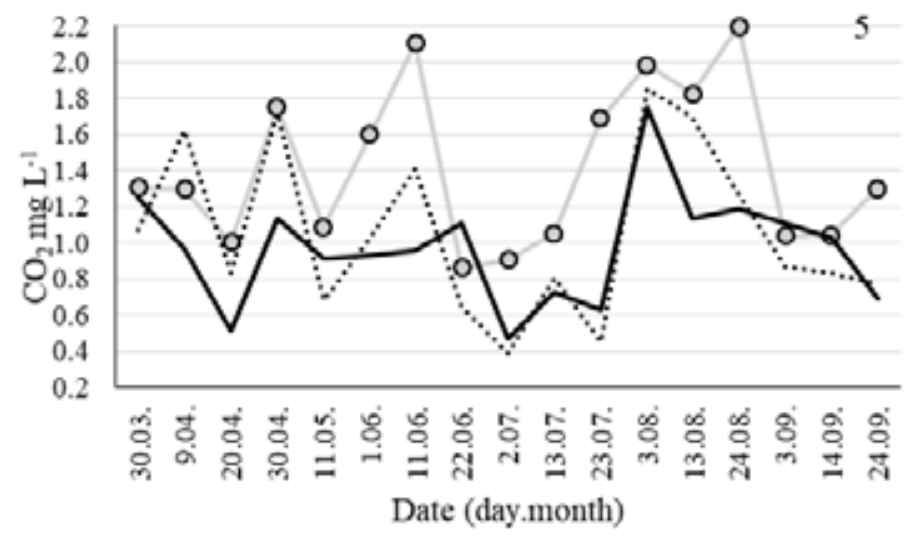

- Bean VF_02。Bean VF_01 $\rightarrow$ Pea Ambrosia - -Pea Capella $*$ Clover …... Control -N $\longrightarrow$ Control $+\mathrm{N}$

Figure 4. Soil respiration rate in the second year of strawberry-legume intercropping system $\left(\operatorname{LSD}_{0.05}=0.12\right)$. 1 - Bean VF_01 compared to both controls, 2 - Bean VF_02 compared to both controls, 3 - Pea 'Capella' compared to both controls, 4 - Pea `Ambrosia` compared to both controls, 5 - Clover compared to both controls.

lower than in the second and the third growing year. It is in line with findings of other research that soil cultivation increases $\mathrm{CO}_{2}$ emission (Schwen, Jetler, \& Böttcher, 2015).

To clarify the influence of the growing technologies on the soil, multiple soil parameters must be monitored. As one of the most important is soil organic matter (SOM) (Figure 5). During monitoring of SOM no significant differences were observed between treatments $(p=0.054)$. Comparing SOM content at the beginning of the experiment to SOM at the end of experiment, only treatment with pea variety 


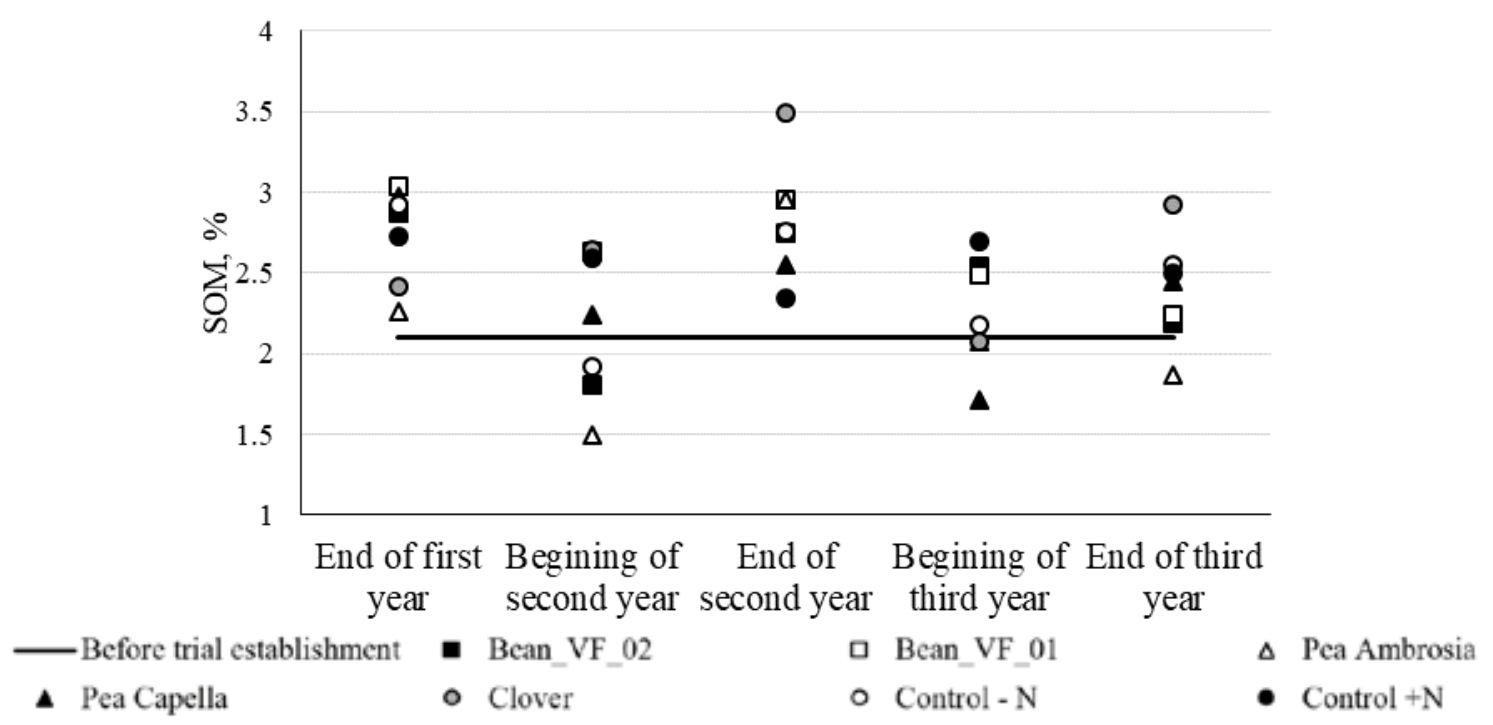

Figure 5. Soil organic matter`s changes during strawberry-legume intercropping trial $\left(\mathrm{LSD}_{0.05}=0.43\right)$.

'Ambrosia' had decreased SOM content. It can be due to its small amount of leaf canopy incorporated in the soil. Small increase in SOM was in treatments with beans and in pea 'Capella' treatment. It can be explained with strawberry mulching. To get clean berries straw mulch was used, and in treatments with beans and peas straws were applied only from the side of unused interrows. That can lead to lower input of organic matter in these treatments. It thus evens organic matter input between treatments by straw mulch and incorporated legume leftovers.

\section{Conclusions}

Trial results show that there were found significant differences between treatments in soil respiration rate and soil respiration rate dynamic all through the experiment time. Dehydrogenase activity also had significant differences between treatments, however, no significant differences were found between treatments in the third year. No significant difference was found between treatments in soil organic matter. Obtained data shows that legumes have a significant influence on the soil biological properties but not on biochemical properties. It gives a starting point in research field for strawberry-legume intercropping influence on soil fertility. Further research needs to be carried out to determine legume influence on the soil environment in more detail.

\section{Acknowledgements}

The research was funded by the European Union's Seventh Framework Programme for research, technological development and demonstration under grant agreement No 613781, EUROLEGUME.

\section{References}

1. Bardgett, R.D., Mamer, L., \& De Vries, F.T. (2014). Going underground: root traits as drivers of ecosystem processes. Trends in Ecology and Evolution. 29(12), 692 - 699. DOI: 10.1016/j.tree.2014.10.006.

2. Bischoff, N., Mikutta, R., Shibistova, O., Puzanov, A., Reichert, E., Silanteva, M., Grebennikova, A., Schaarschmidt, F., Heinicke, S., \& Guggenberger, G. (2016). Land-use change under different climatic conditions: Consequences for organic matter and microbial comunities in Siberian steppe soils. Agriculture, Ecosystem and Environment. 235, 253 - 264. DOI: 10.1016/j.agee.2016.10.022.

3. Brennan, E.B. \& Acosta- Martinez, V. (2017). Cover cropping frequency is the main driver of soil microbial changes during six years of organic vegetable production. Soil Biology and Biochemistry. 109, 188 - 204. DOI: $10.1016 /$ j.soilbio.2017.01.014.

4. Dane, S., \& Šterne, D. (2016). Augsnes auglība zemenuu - taurinzziežu jauktajā stādījumā. (Soil fertility in strawberry - legume intercrop). Ražas svētki 'Vecauce - 201': Lauksaimniecības zinātne nozares attīstībai. Jelgava: LLU. 16 - 19. (in Latvian).

5. Dubova, L. Ruža, A., \& Alsiņa, I. (2016). Soil microbiological activity depending on tillage system and crop rotation. Agronomy Research. 14(4), 1274 - 1284.

6. FAO-stat (17.02.2017). Food supply - Crops primary equivalent. Retrieved March 3, 2017 from http:// www.fao.org/faostat/en/\#data/CC. 
7. Filser, J., Mebes, K.H., Winter, K., Lang, A., \& Kampichler, C. (2002). Long-term dynamics and interrelationships of soil Collembola and microorganisms in an arable landscape following land use change. Geoderma. 105, 201 - 221. DOI: 10.1016/S0016-7061(01)00104-5.

8. Haynes, R.J., Martin, R.J., \& Goh, K.M. (1993). Nitrogen fixation, accumulation of soil nitrogen and nitrogen balance for some field-grown legume crops. Field Crop Research. 35, 85 - 92. DOI: 10.1016/03784290(93)90141-9.

9. Herdina, \& Silsbury, J.H. (1990). Growth, nitrogen accumulation and partitioning, and $\mathrm{N}_{2}$ fixation in faba bean (Vicia faba cv. Fiord) and pea (Pisum sativum cv. Early Dun). Field Crop Research. 24, 173 - 188. DOI: 10.1016/0378-4290(90)90036-B.

10. Jensen, E.S., Peoples, M.B., \& Hauggaard - Nielsen, H. (2010). Faba bean in cropping system. Field Crop Research. 115, 203 - 216. DOI: 10.1016/j.fcr.2009.10.008.

11. Kumar, S., Chaudhuri, S., \& Maiti, S.K. (2013). Soil Dehydrogenase Enzyme Activity in Natural and Mine Soil - A Review. Middle-East Journal of Sciantific Research. 13(7), 898 - 906. DOI: 10.5829/idosi. mejsr.2013.13.7.2801.

12. Nautiyal, C.S., Chaunhan, P.S., \& Bhatia, C.R. (2010). Changes in soil physio-chemical properties and microbial functional diversity due to 14 years of conversion of grassland to organic agriculture in semi-arid agroecosystem. Soil and Tillage Research. 109(2), 55 - 60. DOI: 10.1016/j.still.2010.04.008

13. Schwen, A., Jetler, E., \& Böttcher, J. (2015). Spatial and temporal variability of soil gas diffusivity, its scalding and relevance for soil respiration under different tillage. Geoderm. 259 - 260, 323 - 336. DOI: 10.1016/j.geoderma.2015.04.020.

14. Sønsteby, A., Opstad, N., Myrheim, U., \& Heide, O.M. (2009). Interaction of short day and timing of nitrogen fertilization on growth and flowering of 'Korona' strawberry (Fragaria ×ananassa Duch.). Scientia Horticulturae. 123, 204 - 209. DOI: 10.1016/j.scienta.2009.08.009. 